\title{
Pre-Service English Teachers' Beliefs on Speaking Skill Based on Motivational Orientations *
}

\author{
Ali Dinçer ${ }^{1} \&$ Savaş Yeşilyurt ${ }^{2}$ \\ ${ }^{1}$ Department of English Language Teaching, Erzincan University, Erzincan, Turkey \\ ${ }^{2}$ Department of English Language Teaching, Atatürk University, Erzurum, Turkey \\ * The data in this study was a part of the first author's master's thesis \\ Correspondence: Ali Dinçer, Department of English Language Teaching, Erzincan University, Erzincan, 24100, \\ Turkey. Tel: 90-446-224-0089 (40273). E-mail: adincer@erzincan.edu.tr
}

Received: April 18, 2013 Accepted: May 21, 2013 Online Published: June 3, 2013

doi:10.5539/elt.v6n7p88 URL: http://dx.doi.org/10.5539/elt.v6n7p88

\begin{abstract}
This study aimed to explore pre-service English teachers' perceptions of teaching speaking in Turkey, the importance they give to this language skill, and their self-evaluation of their speaking competence. With case design and maximum variation sampling approach, seven pre-service English teachers' beliefs about speaking skills were gathered in regard to motivational orientations based on Self-determination theory (Deci \& Ryan 2002) and the data was analyzed according to interview questions. Findings revealed that the subjects, whether they were intrinsically or extrinsically motivated to speak English, had negative ideas about speaking instruction in Turkey though they all agreed that it was the most important language skill. The findings also showed that they felt incompetent in oral communication though they had different motivational orientations about speaking English. The findings are significant for understanding speaking instruction in English language classrooms from a motivational perspective and helpful for enhancing learners' speaking ability with intrinsic motivation.
\end{abstract}

Keywords: motivation, competence, speaking instruction, speaking skill, case study

\section{Introduction}

Speaking is often considered as a neglected skill in foreign language education and accepted as the most complex and difficult skill to acquire (Ur, 1996). It is neglected because traditional approaches still exist in the golden age of communicative approaches in language education. In addition, speaking is complex and difficult to master because it contains linguistic and non-linguistic elements such as vocabulary, intonation, articulation, formal and informal expression, gestures, and so forth. Considering its features and difficulty to master, motivation as a key factor in language success is helpful to clearly realize teaching and learning speaking in EFL settings.

The relationship between motivation and success or failure in foreign language learning is still a popular issue despite the thousands of research papers about this concept. Though there is a tremendous literature about ESL/EFL motivation (e.g. Dörnyei, 2001; 2003; Gardner, 1985; Noels, 2001; Ushioda, 2008), each day new research is being conducted to understand different educational settings' unique features. Turkey as an expanding circle country (see Kachru, 1985) is geologically far from inner circle countries such as the UK, the US, and it is a country where English is taught as a foreign language. English learners have little chance to practice English speaking outside the classroom apart from online environments. Therefore, motivating students to learn English and speak English is a challenging task in Turkey. With the present case study, it is aimed to present an overview about teaching speaking in Turkey, and learn the ideas of motivated and unmotivated language learners concerning their speaking skills. The study findings are explorative and productive to understand and lessen some of the problems associated with teaching English speaking in Turkey.

\section{Literature Review}

Motivation, a highly discussed and proven factor in determining language success or failure, is a productive tool in understanding language education contexts deeply. It is often mentioned as a significant psychological factor which enormously affects learners' language education process. Then, its relations with other factors and elements related to educational settings have been researched by a number of prominent researchers over seven 
decades. In sum, the studies researching motivation in second and foreign language environments mentioned many motivation theories such as the socio-educational model, self-determination theory, and put motivation into different categories such as instrumental or integrative, and intrinsic or extrinsic types. The studies generally reveal that students who are intrinsically or integratively motivated to learn a language are better at language performance and achievement (e.g. Dörnyei, 2003; Gardner, 1985).

Whether for intrinsic reasons such as personal happiness and motivation, or extrinsic reasons such as grade, money, fame, using English to communicate orally is one of the sources of motivation, and the primary motivation of a foreign language learner is to be able to converse with speakers of that language (MacIntyre, Clement, Dornyei, \& Noels, 1998, Zhang, 2009). In addition, knowing a language is usually perceived as speaking that language in daily life effectively, and people who know the language are referred to as "speakers" of that language, as if speaking included all other kinds of knowing; and many if not most foreign language learners are primarily interested in learning to speak (Ur, 1996, p. 120).

Despite the fact that speaking can be named as one of the primary motivational resources, and students learning English mostly desire to master English speaking skill among the four major language skills (e.g. Kaçar \& Zengin, 2009; Kim, 1999; Songsiri, 2007), speaking ability is underestimated in foreign language learning contexts and taught with old-fashioned teacher-centred approaches. Teachers taught speaking with the audio-lingual method by forcing students to memorize and repeat conversations from the textbooks for many years. What they did not realize was that the textbook conversations were not realistic and not similar to everyday English in conversations. When educators realized the importance of interaction between speakers in language learning, they turned their views to more modern approaches such as the communicative language teaching method and created content-, task- based teaching methods and activities in the classroom (Nunan, 2003). In spite of the modernization and change in teaching speaking, because of the dominance of traditional approaches in language learning and problems stemming from educational settings especially in EFL contexts, many learners are far away from using language at an adequate communication level.

The current status quo of teaching and learning English at an adequate communication level in Turkey is similar to the situation of China, Thailand, and Japan. Studies conducted in these countries (e.g. Dwyer, \& Heller-Murphy, 1996; Khamkhien, 2010; Liu, 2005; Zhang, 2009) addressed the fact that though lots of time, effort, money have been spent and teaching and learning materials used for the improvement of language education, an average language learner who has taken hundreds of hours of English courses over 10 years of his/her formal and informal education, is still far from speaking English effectively and does not have the courage to initiate a conversation with foreigners in English. Thus, students learn mute English, a dead language and they turn themselves into mute English learners by learning a non-existing language in daily life (Dinçer, Yeşilyurt, \& Göksu, 2012).

Although there are many studies including teaching language skills, there are few studies (e.g. Aydın, 1999; Gençoğlu, 2011; Güney, 2010; İşisağ \& Demirel, 2010; Özsevik, 2010; Paker \& Höl, 2012) dealing specifically with speaking education in Turkey. Most studies about teaching English in the Turkish context generally mention the inadequacy of language teaching and treat language skills as a whole. The main problems in language classrooms in Turkey are generally about out-branch teachers, traditional methods, material inefficacy, low course hours, and negative affective factors. No doubt, these highly cited problems are related with all language learning process and specially speaking skill. Studies related to speaking skill in EFL contexts summarize the main difficulties which make learners reticent and silent in the classrooms as follows: problems stemming from the learning environment, the teacher, content knowledge, affective factors, materials and contextual factors (Güney, 2010). More specifically, the fear of speaking in front of the class, feeling inferior in the class, demotivation to speak English, grammar-based classroom practice, not listening to English much, and lack of autonomy hinder speaking proficiency in Turkey.

The study which is looking at speaking instruction from pre-service EFL teachers' viewpoints accepts intrinsic motivation as a primary impetus to acquire speaking ability and uses motivation as a key psychological factor to improve learners' English speaking skill. It aims to investigate speaking skill from students' perspectives with a qualitative approach and gives pedagogical advice in light of the findings.

\section{Methodology}

One of the qualitative research designs, the case study, which is the most widely used approach in qualitative studies (Gall, Gall, \& Borg, 2003), and which helps researchers to understand a phenomenon in-depth regardless of the numbers of contexts and subjects for the study (McMillan \& Schumacher, 2006) was adopted in the study. From Yin (2003)'s case study designs, multiple-case design with embedded unit of analysis was accepted as a 
model. Therefore, pre-service ELT students' beliefs about speaking instruction and skill in an EFL context were analyzed in regard to motivational factors. With maximum variation sampling method from purposeful sampling strategies, it is deeply analyzed how speaking skill is seen and understood among different motivationally orientated students. Then, 7 pre-service ELT students being intrinsically, extrinsically motivated and amotivated were determined, and their beliefs on speaking skill were collected with interviews and analyzed descriptively.

\subsection{Subjects}

Subjects of the study were comprised of 3 intrinsically motivated, 2 extrinsically motivated and 2 amotivated or unmotivated students who participated in speaking courses in preparatory and first classes of a Turkish university's ELT department. Four of the subjects were female and the rest were male and their age range was 18 to 22 .

\subsection{Instruments}

Instruments in the study are a speaking motivation scale (SMS) adapted from various studies (e.g. Noels, Pelletier, Clément, \& Vallerand, 2000; Yeşilyurt, 2008) by the researchers and an interview form.

SMS is a five point-likert scale having 31 items and used to determine interviewees having different motivational orientations such as intrinsic motivation, extrinsic motivation, and amotivation, and it is prepared according to a motivation theory, Self-determination theory (Deci \& Ryan, 2002). This instrument was used for just determination of the study group.

The interview form includes three semi-structured questions each of which followed by the expression "Please explain!" During the interview, follow-up questions were asked to uncover students' opinions.

\subsection{Data Collection and Analysis}

Data collection procedures include two sections. The first part is about the determination of interviewees and the second part is about the collection of interview data.

Firstly, a consent form including the SMS and voluntary interview section was distributed to a number of EFL pre-service teachers, and the data of the 59 students who fully completed the scale and accepted to be orally interviewed by the first researcher, were analysed with the statistics programme, SPSS 17. After the analysis, the 7 interviewees having different motivational orientations such as intrinsic, extrinsic and amotivation were determined.

Interviews were conducted face to face and one by one in Turkish to allow students to express their thoughts easily and these were recorded via a recorder. The interviewees' average duration for answering three questions was approximately 10 minutes. The interview recordings were transcribed and translated from Turkish to English. In this process, translate-retranslate method was adopted and retranslations were made from English to Turkish and Turkish to English by the authors. Lastly, according to accordance between translations, English translations were agreed and a third expert who is a native speaker of English checked the use of everyday expressions. Answers given to interview questions were descriptively analyzed and presented in tables related to the interview questions.

\section{Findings}

Research findings are presented under three sub-sections based on the interview questions.

\subsection{Teaching Speaking in Turkey}

Frequencies and percentages of students' answers to the first interview question "Do you think that instruction on English speaking ability in the Turkish education system is satisfactory?" is shown in Table 1.

Table 1. Frequencies and percentages on Q1

\begin{tabular}{lllc}
\hline Question-1 & Beliefs & $\mathrm{N}$ & $\%$ \\
\hline Q1-General Beliefs & Adequate & 0 & 0 \\
on Speaking Education & Inadequate & 7 & 100 \\
\hline
\end{tabular}

Table 1 shows that all the subjects think that teaching speaking in the Turkish education system is inadequate and they believe that speaking skill is ignored in primary and high schools, and they have negative ideas about the situation of teaching speaking in state schools. 
One of the subjects, S3 accepting the inadequacy of teaching speaking in state schools said "It is not easy to define the whole education, but I can say that good education has not been given to students until they enter universities." Another subject, S1 added “... I do not think that there are lots of people speaking English adequately in Turkey... In my opinion, a person who has graduated from a high school should speak English at least at a basic communication level, but this education can be supported only in English based high schools."

The students believe that their teachers did not adopted a communicative approach and speaking skill was ignored in their school years. On this issue, S2 said "...Instruction and practice activities about speaking ability are given at university. Instruction in this way is almost non-existent in primary and high school years." Expressing similar ideas with other subjects, the subject S4 said that English teachers in state schools still adopt grammar- based teaching strategies and added "Every year students are taught the same topics and the same rules. English is mostly related to grammar knowledge...."

The subjects generally expressed negative ideas about the situation of teaching speaking in Turkey and agreed that the skill of speaking is often disregarded in formal education institutions. This situation is the result of several problems such as out-branch teachers, strict curricula, teaching the same topics and grammar rules repeatedly, paper-based examinations, little chance to practice, and so forth. In sum, no matter whether they are motivated or unmotivated to speak English, all subjects agree that speaking instruction is neglected in state schools and it is only developed in university education in Turkey.

\subsection{The Placement of Speaking among Four Macro Language Skills}

Frequencies and percentages of students' answers to the second question "Of all four language skills (listening, speaking, writing and reading), in which order do you put the importance of speaking skill in language learning, and why?" are shown in Table 2.

Table 2. Frequencies and percentages on Q2

\begin{tabular}{lllc}
\hline Question-2 & Place & N & $\%^{*}$ \\
\hline Q2-Placement of Speaking & 1. & 4 & 57.12 \\
in Four Basic Language & 2. & 1 & 14.28 \\
Skills & 3. & 0 & 0 \\
& 4. & 2 & 28.56 \\
\hline
\end{tabular}

Not. *Values do not add to $100 \%$ due to rounding.

Students' answers to the question are diverse as shown in the table. This finding can be related to students' being motivated or unmotivated to speak. Most of them (57.12\%) place the skill of speaking first while the others $(42.84 \%)$ place the other skills first. Some of the reasons why they place speaking in first, second and fourth place are as follow:

"I think speaking ability covers other skills and speaking the language is a sign of our English knowledge. Speaking shows the degree of a person's level of education." S4

$\mathrm{S} 1$ articulated "A good level of speaking ability comes first. In our daily lives, I estimate that nearly 90 percent of our communication takes place by speaking. Mostly we transfer our ideas with utterances and we have not enough time to express our ideas in conversation."

Believing that speaking is the second important skill coming after the skill of writing, S2 said "I do not believe that one can speak English without having good knowledge of writing and grammar."

S3 and S7 said that no one could speak the language without having the other three skills and added that listening, reading and writing were more important than learning speaking for accurate communication. S7 said “... Because, to speak, we firstly listen and learn how to pronounce sounds. After then, we reinforce the acquired knowledge with reading and writing skills."

Dividing the four language skills and thinking of them separately is not an easy task as they are actively related to each other but modern language teaching mostly focuses on communicative-oriented language teaching approaches and emphasizes oral communication. Getting ideas about the importance of language skills from motivated and unmotivated students who are studying at language teaching departments can be helpful in 
obtaining ideas about future language teachers.

\subsection{General Competency in English Speaking Ability}

Frequencies and percentages of the responses to the third question "Do you believe that you are competent in English speaking?" are shown in Table 3.

Table 3. Frequencies and percentages on Q3

\begin{tabular}{|c|c|c|c|}
\hline Question-3 & Beliefs & $\mathrm{N}$ & $\%$ \\
\hline \multirow{2}{*}{$\begin{array}{l}\text { Q3- Self-evaluation } \\
\text { Speaking Ability }\end{array}$} & Adequate & 0 & 0 \\
\hline & Inadequate & 7 & 100 \\
\hline
\end{tabular}

Students' ideas on whether they are competent or not in speaking English show that none of them feel competent enough. Some of the reasons why they do not feel competent are as follow:

"As I was not taught in my primary and high school years, I need time. ... I came to university without a good level of preparedness. " S4

Another student, S2 said "I started to practice English only at university and this is too late to get fluency."

S6 emphasized how affective factors influence speaking ability and said "There are some factors which originate from the self such as inhibition, being afraid of making mistakes, etc. To overcome these negative thoughts, we need time."

In general, the subjects feel incompetent in speaking English; this is the result of inadequate teaching practices in primary and high school years in Turkey. Besides, some of them expressed the idea that their English speaking proficiency was better than their classmates and they participated in speaking activities a lot though they felt incompetent in oral communication. They had prior negative experiences in their former education. In addition, they know that gaining speaking accuracy and fluency comes with practice and time, then they are hopeful to promote their speaking skill and gain competency.

\section{Discussion}

The study findings revealed that all the participants whether motivated or amotivated declared that teaching English speaking skill was inadequate in the Turkish education system. They explained their reasons by mentioning the deficiencies mostly related to the education system of Turkey and their course teachers such as lack of instructional practice activities in formal education, strict curricula in primary and high schools, traditional teaching methods, paper-based examinations, out-branch teachers, instruction of the same topics, and little chance to speak. Turkey has experienced significant developments in education policies and gone through reforms from the introduction of English in Turkey to today depending on Turkey's changing economic and political aims such as to be a part of the European Union (see Doğançay-Aktuna \& K1zıltepe, 2005; Kırkgöz; 2007; 2009). Thanks to educational reforms and changes in Turkish education policy, the above stated problems which hinder speaking proficiency have been lessened and communicative language teaching approach has become a central point in all levels of English education after revisions (see MEB; 2006, 2013). But as stated in the studies of Kırkgöz (2009) and Sarıçoban \& Sarıçoban (2012), there is still a discrepancy between the developments and educational policies and objectives in Turkey. When this existing inconsistency is realized, the changes in Turkey's prevailing foreign language education policy will be more effective and coherent in the progress of teaching English (Kırkgöz, 2009).

Students' ideas about the importance of speaking skill among the four language skills are diverse; this diversity is associated with the students' motivational orientations and students' feeling competent/incompetent in speaking. Students who have low engagement and proficiency believe that speaking is the least important skill and it comes after listening, writing and reading. Students who place speaking first generally think that speaking is a sign of knowing a language and it is the most important skill in daily communication. The other subjects think that ability in listening, reading and writing compose the speaking skill and efficient ability in these skills helps learners to speak accurately. The reason for this diversity can be related to motivational orientations of students as well. Students who are motivated to gain speaking competency for intrinsic and extrinsic reasons such as for pleasure, personal development, pride, reward are more likely to feel the importance of an activity than unmotivated or amotivated ones who are not interested in speaking activities and do not care about speaking English. Amotivated students experience feelings of incompetence and they do not recognize the importance of 
an activity. In other words, these can be related to links between motivation and cognition which reveal that motivational factors such as goals, values, efficacy beliefs, and control beliefs can be effective on students' mental concepts (Eccles \& Wigfield, 2002). In addition, self-concepts and motivation are associated with each other, and perceptions about one's abilities and competences effect motivation (Ďuricová, 2009).

Students' self-assessment about their speaking ability was generally negative and they expressed themselves as incompetent speakers. Few of them said that, compared to other students, they had a better position both in participating in speaking activities and speaking English. The reasons for their negative feelings are generally related to prior language learning experiences in the education system. Almost all the subjects said that speaking skill is emphasized in their university lives but they were not taught effectively during their primary and high school years. Hopefully, all students are aware that gaining fluency in speaking takes time and they think they can master oral communication in the future. Besides, some students underestimate their speaking proficiency though they are really good speakers. Feeling competent or incompetent is mostly about self-perceptions about actual proficiency in English. The reason of the underestimation can stem from speaking anxiety and motivation. According to MacIntyre, Noels, \& Clément (1997), "self-derogation" is seen in more anxious students, and these students have a tendency to underestimate their actual competence to speak. However, Ames (1990) focusing on the relationship between motivation and confidence, claims that learners who have negative thoughts about their competency avoid taking responsibility to succeed and even underestimate their performance when they do well.

\section{Suggestions}

Solving problems related to teaching speaking skill in an EFL context is not an easy task because some of the problems are closely associated with the Turkish education system and English teachers. In spite of the developments in the education system (e.g. adopting communicative approach, focusing on primary English teaching, applying Common European Framework (CEF)), teachers cannot update and adapt themselves easily to new education objectives and they experience problems in applying instructional practices related to teaching speaking in language classrooms in Turkey. Therefore, to lessen the gap between educational policy and teachers' existing knowledge, classroom applications of the communicative approach, activities related to teaching speaking comprising of all primary, secondary, high school, and university level English teaching should be introduced to teachers with different educational activities such as in-service teaching trainees, workshops, seminars, conferences, webinars.

Considering the study findings and students' self-reports on teaching speaking, to enhance learners' speaking skill and get them to speak in the class, the following suggestions related to the research can also be offered for teachers. They should use different methods and speaking activities in the class and lessen their speaking time and increase learners' speaking duration. They should refrain from only paper-based examinations and add listening and speaking skills to exams. They should teach language functions in discourse, which helps students master fluency and accuracy in speaking. In this way, students can gain linguistic competency which is a prerequisite for better speaking. Besides this instructional advice, teachers should acknowledge affective sides of learners and try to create an autonomy-supportive environment by supporting an anxiety-free classroom climate. They should listen to students' ideas and give them chances to choose speaking topics. They should intrinsically motivate learners to participate in the course by caring about their interests and needs. Therefore, teachers can cure students' negative self-assessments about their competencies, encourage them to attain personal intrinsic goals in learning and motivate them for long-term speaking achievement.

\section{References}

Ames, C. (1990). Motivation: What teachers need to know. Teachers College Record, 91(3), 409-421.

Aydın, B. (1999). A study of the sources of foreign language classroom anxiety in speaking and writing classes (Unpublished Ph.D. dissertation). Anadolu University, Eskişehir, Turkey.

Deci, E. L., \& Ryan, R. M. (2002). Handbook of self-determination research. Rochester: The University of Rochester Press.

Dinçer, A., Yeşilyurt, S., \& Göksu, A. (2012). Promoting speaking accuracy and fluency in foreign language classrooms: A closer look at English speaking classrooms. Erzincan University Journal of Erzincan Faculty of Education, 14(1), 97-108.

Doğançay-Aktuna, S., \& Kızıltepe. Z. (2005). English in Turkey. World Englishes, 24(2), 253-265. http://dx.doi.org/10.1111/j.1467-971X.2005.00408.x

Dörnyei, Z. (2001). Teaching and researching motivation. Harlow, England: Pearson Education Limited. 
Dörnyei, Z. (2003). Attitudes, orientations, and motivations in language learning: Advances in theory, research, and applications. Language Learning, 53(1), 3-32. http://dx.doi.org/10.1111/1467-9922.53222

Ďuricová, L. (2009). Self-concept of university students and their motivation. The New Educational Review, 17, 264-275.

Dwyer, E., \& Heller-Murphy, A. (1996). Japanese learners in speaking classes. Edinburgh Working Papers in Applied Linguistics, 7, 46-55.

Eccles, J. S., \&Wigfield, A. (2002). Motivational beliefs, values, and goals. Annual Review of Psychology, 53, 109-132. http://dx.doi.org/10.1146/annurev.psych.53.100901.135153

Gall, M. D., Gall, J. P., \& Borg, W. T. (2003). Educational research (7th ed.). White Plains, NY: Pearson Education.

Gardner, R. C. (1985). Social psychology and second language learning: The role of attitudes and motivation. London: Edward Arnold.

Gençoğlu, G. (2011). Improving adult efl learners' speaking skills through strategies-based instruction (Unpublished master's thesis). Çukurova University, Adana, Turkey.

Güney, İ. (2010). An investigation into the causes of speaking problems experienced by learners of English at tertiary level (Unpublished master's thesis). Çanakkale Onsekiz Mart University, Çanakkale, Turkey.

İşisağ, K. U., \& Demirel, Ö. (2010). The use of the Common European Framework of Reference for languages on developing the dpeaking skills. Science and Education, 35(156), 190-204.

Kachru, B. B. (1985). Standards, codification and sociolinguistic realism: The English language in the outer circle. In R. Quirk, \& H. G. Widdowson (Eds.), English in the world: Teaching and learning the language and literature (pp. 11-30). Cambridge: Cambridge University Press.

Kaçar, I. G., \& Zengin, B. (2009). İngilizceyi yabancı dil olarak öğrenenlerin dil öğrenme ile ilgili inançları, öğrenme yöntemleri, dil öğrenme amaçları ve öncelikleri arasındaki ilişki: Öğrenci boyutu. Journal of Language and Linguistic Studies, 5(1), 55-89.

Khamkhien, A. (2010). Teaching English speaking skills and English speaking tests in the Thai context: A reflection from Thai perspective. English Language Teaching, 3(1), 184-190.

Kırkgöz, Y. (2007). English language teaching in Turkey: Policy changes and their implementations. Regional Language Centre Journal, 38(2), 216-228.

Kırkgöz, Y. (2009). Globalization and English language policy in Turkey. Educational Policy, 23(5), $663-684$. http://dx.doi.org/10.1177/0895904808316319

Kim, D. (1999). Improving English speaking accuracy and fluency: Applications within a Korean EFL setting. Journal of English Language Teaching, 11, 153-175.

Liu, M. (2005). Reticence in oral English language classrooms: A case study in China. TESL Reporter, 38(1), $1-16$.

MacIntyre, P. D., Clement, R. Dornyei, Z., \& Noels, K. A. (1998). Conceptualizing willingness to communicate in a L2: A situational model of L2 confidence and affiliation. The Modern Language Journal, 82, 545-562.

MacIntyre, P. D., Noels, K. A., \& Clément, R. (1997). Biases in self-ratings of second language proficiency: The role of language anxiety. Language Learning, $47(2), \quad$ 265-287. http://dx.doi.org/10.1111/0023-8333.81997008

McMillan, J. H., \& Schumacher, S. (2006). Research in education: Evidence-based inquiry (6th ed.). New York: Pearson.

MEB - T. C. Milli Eğitim Bakanlığ1 - [Republic of Turkey, Ministry of National Education]. (2006). Illkögretim Ingilizce dersi (4, 5, 6, 7 ve 8. sinıflar) ögretim programı [English language curriculum for primary education (grades 4, 5, 6, 7 and 8)]. Ankara, Turkey. Retrieved from http://ttkb.meb.gov.tr/program2.aspx/program2.aspx?islem $=1 \& \mathrm{kno}=31$

MEB -T. C. Milli Eğitim Bakanlığı - [Republic of Turkey, Ministry of National Education]. (2013). Ilkögretim kurumlari (ilkokullar ve ortaokullar) İngilizce dersi $(2,3,4,5,6,7$ ve 8. siniflar) ögretim programi [English language curriculum for primary and secondary education (grades 2, 3, 4, 5, 6, 7 and 8]. Ankara, Turkey. Retrieved from http://ttkb.meb.gov.tr/program2.aspx/program2.aspx?islem=1\&kno=214 
Noels, K. A. (2001). Learning Spanish as a second language: Learners' orientations and perceptions of their teachers' communication style. Language Learning, 51(1), 107-144.

Noels, K. A., Pelletier, L. G., Clément, R., \& Vallerand, R. J. (2000). Why are you learning a second language? Motivational orientations and self- determination theory. Language Learning, 50(1), 57-85. http://dx.doi.org/10.1111/0023-8333.00111

Nunan, D. (2003). Practical English language teaching. NY: McGraw-Hill.

Özsevik, Z. (2010). The use of Communicative Language Teaching (CLT): Turkish EFL teachers' perceived difficulties in implementing CLT in Turkey (Unpublished master's dissertation). University of Illinois, USA.

Paker, T., \& Höl, D. (2012). Attitudes and perceptions of the students and instructors towards testing speaking communicatively. Pamukkale University Journal of Education, 32(2), 13-24.

Sarıçoban, G., \& Sarıçoban, A. (2012). Atatürk and the history of foreign language education. The Journal of Language and Linguistic Studies, 8(1), 24-49.

Songsiri, M. (2007). An action research study of promoting students' confidence in speaking English (Unpublished Ph.D. dissertation). Victoria University, Australia.

Ur, P. (1996). A course in language teaching: Practice and theory. Cambridge: Cambridge University Press.

Ushioda, E. (2008). Motivation and good language learners. In Griffiths, C. (Ed.), Lessons from good language learners (pp. 19-34). Cambridge: Cambridge University Press. http://dx.doi.org/10.1017/CBO9780511497667.004

Wolff, M. (2010). China's English mystery - the views of a China 'foreign expert'. English Today, 26(4), 53-56. http://dx.doi.org/10.1017/S0266078410000350

Yeşilyurt, S. (2008). A self- determination approach to teaching writing in pre-service EFL teacher education (Unpublished Ph.D. dissertation). Atatürk University, Erzurum, Turkey.

Yin, R. (2003). Case study research: Design and methods (3rd ed.). Thousand Oaks, CA: Sage.

Zhang, Y. (2009). Reading to speak: Integrating oral communication skills. English Teaching Forum, 1(1), 32-34.

\section{Copyrights}

Copyright for this article is retained by the author(s), with first publication rights granted to the journal.

This is an open-access article distributed under the terms and conditions of the Creative Commons Attribution license (http://creativecommons.org/licenses/by/3.0/). 